\title{
Modified Low Density Lipoprotein and Its Constituents Augment Cytokine-activated Vascular Cell Adhesion Molecule-1 Gene Expression in Human Vascular Endothelial Cells
}

\author{
Bobby V. Khan, ${ }^{*}$ Sampath S. Parthasarathy, ${ }^{\ddagger}$ R. Wayne Alexander, ${ }^{*}$ and Russell M. Medford \\ $*$ Department of Medicine, Division of Cardiology and ${ }^{\ddagger}$ Department of Gynecology and Obstetrics, Emory University \\ School of Medicine, Atlanta, Georgia 30322
}

\begin{abstract}
Early features in the pathogenesis of atherosclerosis include accumulation of oxidized LDL (oxLDL) and endothelial expression of the vascular adhesion molecule VCAM-1. Because antioxidants inhibit endothelial VCAM-1 expression, we tested the hypothesis that oxLDL functions as a prooxidant signal in atherogenesis to augment VCAM-1 activation by inflammatory signals. Cultured human aortic endothelial cells (HAECs) or human umbilical vein endothelial cells (HUVECs) were incubated with unmodified LDL, oxLDL, or glycated LDL for $\mathbf{4 8}$ h. No change in VCAM-1, intercellular cell adhesion molecule-1 (ICAM-1), or E-selectin expression from control was observed by ELISA. However, doseresponse and time course studies demonstrated that oxLDL enhanced VCAM-1 expression induced by the cytokine tumor necrosis factor $\alpha$ (TNFa) $63 \%$ in HAECs and $45 \%$ in HUVECs over unmodified LDL or control. Using flow cytometry analysis, oxLDL augmented TNF $\alpha$-induced VCAM-1 expression in a uniform HAEC population. oxLDL had no effect on E-selectin induction. oxLDL augmented TNF $\alpha$-induced ICAM-1 expression $44 \%$ in HAECs but not in HUVECs. Glycated LDL augmented TNFa-induced VCAM-1 expression 35\% in HAECs but not HUVECs. Similar results were obtained with 13-HPODE or lysophosphatidylcholine, significant components of oxLDL. 13-HPODE augmented TNF $\alpha$-induced mRNA accumulation and transcriptional activation of VCAM-1 in HAECs. These results suggest that as long-term regulatory signals, specific oxidized fatty acid and phospholipid components of oxLDL augment the ability of vascular endothelial cells to express cytokine-mediated VCAM-1. These studies link oxidant signals conferred by oxLDL to oxidation-sensitive regulatory mechanisms controlling the expression of endothelial cell adhesion molecules involved in early atherosclerosis. $(J$. Clin. Invest. 1995. 95:1262-1270.) Key words: lipoprotein • fatty acid hydroperoxide - adhesion - oxidation - endothelium
\end{abstract}

Address correspondence to Dr. Russell M. Medford, Emory University School of Medicine, Division of Cardiology, PO Drawer LL, Atlanta, GA 30322.

Received for publication 31 March 1994 and in revised form 18 October 1994.

J. Clin. Invest.

(C) The American Society for Clinical Investigation, Inc.

0021-9738/95/03/1262/09 \$2.00

Volume 95, March 1995, 1262-1270

\section{Introduction}

Several lines of evidence point to the key role of inflammatory processes in the pathogenesis of atherosclerosis (1-6). It has been shown that endothelial cell activation, by cytokines and other inflammatory mediators, results in the synthesis of binding molecules and chemotactic factors and increases interactions with leukocytes (7-11). Endothelial cells play a major role in defining the types of leukocytes recruited, such as monocytes, lymphocytes, or neutrophils, by selectively expressing specific adhesion molecules, such as vascular cell adhesion molecule-1 (VCAM-1), ${ }^{1}$ intercellular adhesion molecule-1 (ICAM-1), or E-selectin, in response to various inflammatory stimuli (1214). The adhesion of leukocytes is believed to be based on a cascade of molecular interactions and is mediated by multiple cell adhesion molecules $(10,15)$.

Modulation of the expression and function of vascular genes by oxidative signals may be an important mechanism through which inflammatory signals initiate and propagate atherosclerosis. Endothelial expression of the cell surface adhesion molecule VCAM-1 is an early, inducible event in experimental models of atherogenesis preceding the accumulation of inflammatory mononuclear leukocytes (16). Consistent with the notion that oxidative stress plays an important role in atherogenesis, activation of endothelial VCAM-1 gene expression by diverse inflammatory signals occurs through an antioxidant-inhibitable mechanism that involves a reduction-oxidation (redox) -sensitive activation of an NF- $\kappa$ B-like transcription factor (13). This mode of regulation distinguishes VCAM-1 from other inducible adhesion molecules, such as ICAM-1 and E-selectin (13), and suggests that VCAM-1 may represent a useful experimental paradigm to explore the linkage between oxidative modulatory signals and nuclear regulatory mechanisms in the vasculature.

Oxidatively modified LDL (oxLDL) has been implicated as an important oxidative signal in the pathogenesis of atherosclerosis. oxLDL accumulates and is preferentially synthesized at sites of the vascular wall predisposed to atherosclerosis (17, 18). Although its precise mechanism of formation is not known, LDL may be modified through lipid peroxidation in the formation of fatty acid hydroperoxides $(19,20)$, resulting in novel epitopes generated on oxLDL that are recognized by macrophage "scavenger" receptors (19). Though still controversial, cellular lipoxygenases may mediate LDL oxidation in several

1. Abbreviations used in this paper: HAEC, human aortic endothelial cell; 13-HPODE, linoleyl hydroperoxide; HUVEC, human umbilical vein endothelial cell; ICAM-1, intercellular cell adhesion molecule1; lyso-PC, lyso-phosphatidylcholine; MDA, malondialdehyde; oxLDL, oxidized low density lipoprotein; TNF $\alpha$, tumor necrosis factor- $\alpha$; VCAM-1, vascular cell adhesion molecule-1. 
cell types: LDL treated with soybean lipoxygenase and phospholipase $A_{2}$ closely resembles oxLDL (21). It has also been shown that there are higher levels of 15-lipoxygenase enzymatic activity in atherosclerotic lesions of rabbit and human aorta than in corresponding normal arteries $(22,23)$. Other modifications, such as glycated LDL (the nonenzymatic binding of glucose to LDL observed primarily in diabetes mellitus), may be predisposed to further oxidization (24). Recently, Richardson et al. (25) have demonstrated that there is increased expression in vivo of VCAM-1 and E-selectin by the aortic endothelium of normolipemic and hyperlipemic diabetic rabbits, providing at least a partial mechanism for the enhanced atherosclerosis associated with diabetes mellitus $(26,27)$.

oxLDL exhibits a wide variety of potentially atherogenic properties in vitro, including stimulation of monocyte migration (28) and inhibition of endothelium-dependent vasodilatation $(29,30)$. Although oxLDL itself does not appear to induce adhesion molecule gene expression, at least one potential component of the oxLDL complex, lyso-phosphatidylcholine (lysoPC), does acutely induce a transient expression of VCAM-1 and ICAM-1 in cultured human aortic endothelial cells (31). Importantly, these studies have focused on the role of oxLDL as an acute, primary regulatory signal controlling vascular cell function and gene expression. Yet, it is likely that chronic exposure of vascular cells to oxLDL is another important characteristic of the atherogenic lesion. In this context, oxLDL may serve to modulate the response of vascular endothelial cells to a wide variety of acute, primary regulatory signals such as inflammatory cytokines. The molecular mechanisms underlying either the acute or the potentially chronic effects of oxLDL on vascular gene expression are unknown.

We have tested the hypothesis that oxLDL, as well as specific fatty acid hydroperoxide and phospholipid components of oxLDL, serves as an oxidative signal that selectively augments redox-sensitive VCAM-1 gene expression in vascular endothelial cell. These studies begin to address the role and molecular mechanisms of action of specific oxidative signals in the sensitization of the vasculature to otherwise physiological signals that may underlie the pathogenesis of atherosclerosis.

\section{Methods}

Cell types used. Human umbilical vein endothelial cells (HUVECs), purchased from Clonetics, Inc. (San Diego, CA) were cultured in Gibco M199 medium (Life Technologies, Inc., Grand Island, NY) supplemented with $15 \% \mathrm{FBS}, 50 \mu \mathrm{g} / \mathrm{ml}$ endothelial cell growth supplement, $25 \mathrm{mM}$ Hepes buffer, $2 \mathrm{mM}$ L-glutamine, $100 \mathrm{U} / \mathrm{ml}$ penicillin, and $100 \mathrm{U} / \mathrm{ml}$ streptomycin. Human aortic endothelial cells (HAECs), also purchased from Clonetics, Inc., were cultured in M199 medium supplemented with $10 \mathrm{ng} / \mathrm{ml}$ endothelial cell growth supplement, $15 \% \mathrm{FBS}$, $10 \mu \mathrm{g} / \mathrm{ml}$ hydrocortisone, and $2 \mathrm{mM}$ L-glutamine. Cells were grown at $37^{\circ} \mathrm{C}$ on tissue culture plates and used for experimentation at no greater than passage 8 . HUVECs were grown on plates specially coated with $0.1 \%$ gelatin.

Preparation of $L D L$. Human LDL ( $d 1.019-1.063 \mathrm{~g} / \mathrm{ml}$ ) was isolated from EDTA-treated plasma by density gradient centrifugation and pooled; the solvent density was adjusted to 1.020 by a high density salt solution containing $\mathrm{KBr}, \mathrm{NaCl}$, and EDTA. Ultracentrifugation was performed for $18 \mathrm{~h}$ at $50,000 \mathrm{rpm}$ in a 50.2 rotor. The supernatant was collected and dialyzed extensively against isotonic saline and $0.5 \mathrm{mM}$ EDTA (32). The LDL supernatant was again ultracentrifuged for $18 \mathrm{~h}$ at $50,000 \mathrm{rpm}$ in a 50.2 rotor. The supernatant LDL was collected and dialyzed extensively against isotonic saline and $0.5 \mathrm{mM}$ EDTA. Oxidation of LDL was performed by dialysis against EDTA-free iso- tonic saline supplemented with $4 \mu \mathrm{M} \mathrm{CuSO}_{4}$ at $37^{\circ} \mathrm{C}$ for $18 \mathrm{~h}$. Glycation of LDL was performed by techniques described by Schleicher et al. (33). All LDL preparations were stored in PBS. The extent of oxidation of the LDL preparations was measured by the thiobarbituric acid reactivity assay as described previously (34). Malondialdehyde (MDA) was used as a standard, and the thiobarbituric acid-reactive substances were recorded as equivalents of MDA per mg of LDL protein. LDL protein was calculated by the techniques of Lowry et al. (35). The degree of oxidation of the LDL preparations was as follows: native LDL, $1.76 \pm 0.39$; oxLDL, $35.51 \pm 5.23$; and glycated LDL, $2.44 \pm 0.53 \mathrm{MDA}$ equivalents per $\mathrm{mg}$ of LDL protein. The degree of protein glycation of the glycated LDL particle was determined by the fructosamine assay as described previously (36). There was a 6.1-fold increase in glycation products after extensive exposure to high concentrations of glucose in vitro. The concentration of LPS for all LDL preparations was $<5 \mathrm{pg}$ per $100 \mu \mathrm{g}$ of LDL protein, as measured by the chromogenic Limulus test (37).

Endothelial cell culture. HUVECs and HAECs in M199 were plated in 96-well plates. The cells were then incubated at $37^{\circ} \mathrm{C}$ in a tissue culture incubator containing $5.0 \% \mathrm{CO}_{2}$ with their respective media containing no LDL, or $100 \mu \mathrm{g} / \mathrm{ml}$ unmodified (native LDL), oxLDL, or glycated LDL, for a 48-h period. Viability of the cells was determined by microscopic evaluation and by trypan blue exclusion; the viability of the cells was $>90 \%$ after a $48-h$ incubation period. The cells were then exposed to tumor necrosis factor $\alpha$ (TNF $\alpha ; 0-100 \mathrm{U} / \mathrm{ml}$ ) and incubated for $6 \mathrm{~h}$. Human recombinant TNF $\alpha$ was obtained from Boehringer Mannheim Biochemicals (Indianapolis, IN). The cells were then removed from the tissue culture incubator and prepared for ELISA of VCAM-1, ICAM-1, and E-selectin (see below).

Effect of hydroperoxide and lyso-PC formation on cell surface expression of adhesion molecules. HAECs in M199 medium were plated in 96-well plates, as previously described. Linoleic acid, purchased from Cayman Chemical (Ann Arbor, MI), was converted to linoleyl hydroperoxide (13-HPODE) via the addition of 15-lipoxygenase $(17,38)$. Additionally, a preparation of 13-HPODE was purchased commercially from Cayman Chemical. No appreciable differences in biological effects were seen in these two separate preparations. The preparation was added to HAECs ( final concentration, $30 \mu \mathrm{M}$ ) and incubated for a 48-h period. lyso-PC ( $50 \mu \mathrm{M})$, purchased from Calbiochem-Behring Corp. (La Jolla, CA), was added to HAECs for a 48 -h period. The cells were then exposed to TNF $\alpha$ at doses of $10,25,50$, and $100 \mathrm{U} / \mathrm{ml}$ for a $6-\mathrm{h}$ period at $37^{\circ} \mathrm{C}$. Cells were then removed from the tissue culture incubator and prepared for ELISA of VCAM-1, ICAM-1, and/or E-selectin cell surface expression.

ELISA of cell adhesion molecule expression. HUVECs and HAECs were plated on 96-well tissue culture plates. Primary antibodies in M199 medium with 5\% FBS were added to each well and incubated for 30 $\mathrm{min}$ at $37^{\circ} \mathrm{C}$. The cells were then washed and incubated for $30 \mathrm{~min}$ with peroxidase conjugated with goat anti-mouse IgG (Bio-Rad Laboratories, Richmond, CA) diluted 1:500 in M199 medium with 5\% FBS. The wells were then washed, and the binding of antibody was detected

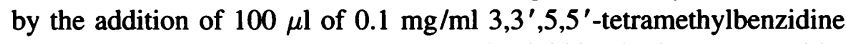
(Sigma Chemical Co., St. Louis, MO) with $0.003 \%$ hydrogen peroxide. The reaction was stopped by the addition of $25 \mu \mathrm{l}$ of $8 \mathrm{~N}$ sulfuric acid. Plates were read on an ELISA reader (Bio-Rad Laboratories, Hercules, CA) at OD $450 \mathrm{~nm}$ after blanking on rows stained only with second step antibody. All data points were performed at least in triplicate.

Fluorescence immunoassay. Confluent HAECs in $150-\mathrm{mm}^{2}$ plates were treated in M199 medium with 13-HPODE (30 $\mu \mathrm{M})$ and oxLDL $(100 \mu \mathrm{g} / \mathrm{ml})$ at $37^{\circ} \mathrm{C}$ for $48 \mathrm{~h}$. HAECs were then treated or not with $\mathrm{TNF} \alpha(100 \mathrm{U} / \mathrm{ml})$ for $6 \mathrm{~h}$. At the end of the incubation, the cells were washed with M199 medium and incubated on ice for $1 \mathrm{~h}$ with mAb against human VCAM-1 (Southern Biotechnology, Birmingham, AL). Subsequently, HAECs were washed three times with PBS and then incubated on ice for $1 \mathrm{~h}$ with FITC-conjugated anti-mouse IgG antibody (Southern Biotechnology). After washing four times with PBS, the cells were lysed with $0.01 \%$ (wt/vol) $\mathrm{NaOH}, 0.1 \%$ SDS buffer for $30 \mathrm{~min}$ at room temperature. The fluorescence of the cell lysate was determined 
with emission maximum at $520 \mathrm{~nm}$ and excitation at $488 \mathrm{~nm}$, using a fluorescence spectrophotometer (Becton-Dickinson, San Jose, CA). Specific cell surface mAb binding in this assay was calculated by subtracting the fluorescence detected in endothelial cell monolayers incubated in the absence of primary mAb (39).

Northern blot analysis. Total cellular RNA was isolated by a single extraction using acid guanidinium thiocyanate-phenol-chloroform (40). Total cellular RNA ( $20 \mu \mathrm{g}$ ) was size fractionated using $1 \%$ agarose-formaldehyde gels in the presence of $1 \mu \mathrm{g} / \mathrm{ml}$ ethidium bromide. Transfers of RNA and hybridizations were performed as described previously (13). After hybridization, filters were washed at a final stringency of $0.2 \times \mathrm{SSC}(1 \times$ is $150 \mathrm{mM} \mathrm{NaCl}, 15 \mathrm{mM}$ sodium citrate $)$ at $55^{\circ} \mathrm{C}$. Autoradiography was performed with an intensifying screen at $-70^{\circ} \mathrm{C}$. Laser densitometry and digital analysis of scanned images were used for quantitation of autoradiograms.

Transcriptional analysis. Early passaged HAECs in $150-\mathrm{mm}^{2}$ culture dishes were treated with linoleic acid (30 $\mu \mathrm{M})$ or 13-HPODE (30 $\mu \mathrm{M})$ for $48 \mathrm{~h}$ and then exposed to TNF $\alpha(100 \mathrm{U} / \mathrm{ml})$ for $3 \mathrm{~h}$. Nuclei were prepared, and transcriptional rates were determined by nuclear run-off analysis as previously described (41). Briefly, nuclei were labeled with $10 \mathrm{mCi} / \mathrm{ml}\left[\alpha-{ }^{32} \mathrm{P}\right] \mathrm{UTP}$. The RNA was isolated and then hybridized to filter-immobilized, denatured plasmids containing specific cDNA inserts (10 $\mu \mathrm{g}$ of DNA per slot) of VCAM- 1 and $\beta$-actin (plasmids were obtained from B. Gopal, Otsuka America Pharmaceuticals, Bethesda, MD). Imaging was performed using the PhosphorImager 445Si (Molecular Dynamics, Sunnyvale, CA) and NIH Image 1.55 computer software (Wayne Rasband, Bethesda, MD).

Statistics. Experiments involving cell surface expression of cell adhesion molecules were performed (in triplicate) on five separate occasions involving three different batches of $\mathrm{LDL}$, and consistent results were observed. HAECs were used at passages 3-8 during these experiments, and no significant difference in the response to cytokine induction of cell adhesion molecules was noted. Values presented are means Istandard error of measurement. Statistics were performed by using an unpaired Student's $t$ test. Significance was determined at the $95 \%$ confidence level.

\section{Results}

oxLDL selectively augments TNF $\alpha$ induction of VCAM-1 gene expression in both arterial- and venous-derived vascular endothelial cells. We have previously reported that antioxidants inhibit cytokine-mediated activation of VCAM-1 gene expression in cultured HUVECs (13). To determine whether oxLDL, a naturally occurring oxidant associated with atherogenic lesions $(19,23,38)$, could have the opposite effect, both HUVECs and early passaged HAECs were incubated for $48 \mathrm{~h}$ with either unmodified LDL, oxLDL, or glycated LDL at $100 \mu \mathrm{g} / \mathrm{ml}$. Glycated LDL, a form of LDL found in diabetic patients, was prepared according to standard procedures (see Methods) to test whether other forms of modified LDL had properties similar to or distinct from those of oxLDL. As shown in Fig. 1, preincubation alone (closed boxes) with native LDL (lanes 3 and 11), oxLDL (lanes 5 and 13), or glycated LDL (lanes 7 and 15) had no significant effect on cell surface expression of VCAM$1(A$ and $B)$, ICAM-1 ( $C$ and $D)$, or E-selectin $(E$ and $F$ ) in either HUVECs $(A, C$, and $E)$ or HAECs $(B, D$, and $F)$. This suggests that long-term exposure to either native or modified LDLs has no significant effect on the basal cell surface expression of these adhesion molecules in unactivated vascular endothelial cells.

Modified LDLs did effect a significant change in cytokine induction of VCAM-1 gene expression in both HUVECs and HAECs. As shown in Fig. 1, preincubation with native LDL at $100 \mu \mathrm{g} / \mathrm{ml}$ for $48 \mathrm{~h}$ (striped boxes, lanes 4 and 12) had no effect on the ability of TNF $\alpha$ alone (6-h exposure; lanes 2 and 10) $(100 \mathrm{U} / \mathrm{ml})$ to induce VCAM-1, E-selectin, or ICAM-1 expression in either cell type. However, preincubation with oxLDL augmented TNF $\alpha$ induction of VCAM-1 expression an additional $45 \%(P<0.05)$, (Fig. $1 A$, lane 6$)$ and $64 \%(P$ $<0.05$ ) (Fig. $1 B$, lane 14 ) in both HUVECs and HAECs, respectively. In contrast, oxLDL had no effect on TNF $\alpha$ induction of E-selectin expression in either cell type (Fig. $1 E$ and $F$, lanes 6 and 14 ) or ICAM-1 expression in HUVEs ( $C$, lane 5 ). oxLDL did augment TNF $\alpha$ activation of ICAM-1 expression in HAECs by $36 \%$ (Fig. $1 \mathrm{D}$, lane 14 ). Glycated LDL augmented TNF $\alpha$ activation of VCAM-1 expression in HAECs by $35 \%$ ( $P$ $<0.05$ ) (Fig. $1 \mathrm{~B}$, lane 16) but not in HUVECs, nor did it affect ICAM-1 or E-selectin expression in either cell type.

To explore further the augmentation of modified LDL on VCAM-1 gene expression, control and preincubated HAECs were exposed to TNF $\alpha(100 \mathrm{U} / \mathrm{ml})$ for varying times up to 24 $h$ and then assayed for cell surface VCAM-1 expression by ELISA. As shown in Fig. 2, in both control and native LDLtreated cells, VCAM-1 expression was transiently induced, peaking at $\sim 8 \mathrm{~h}$ and then gradually declining over $24 \mathrm{~h}$. Preincubation with either oxLDL or glycated LDL significantly augmented TNF $\alpha$-induced VCAM-1 during its peak expression between 4 and $12 \mathrm{~h}$. No significant differences in expression were observed at $24 \mathrm{~h}$. This suggests that modified LDLs augment cytokine activation of VCAM-1 gene expression in HAECs without altering its characteristic transient pattern of induction and deinduction.

13-HPODE and lyso-PC selectively augment TNF $\alpha$ activation of VCAM-1 cell surface protein expression in HAECs. oxLDL is a complex structure consisting of at least several chemically distinct oxidants $(18,19)$, each of which, alone or in combination, might modulate cytokine-activated adhesion molecule gene expression. Fatty acid hydroperoxides, such as 13-HPODE (derived from a polyunsaturated free fatty acid, linoleic acid), are abundant components of oxLDL $(23,36)$ and might serve as a specific redox signal in the expression of cell adhesion molecules in endothelial cells. To determine whether this chemically defined component of oxLDL alone modulates adhesion molecule gene expression, HAECs were preincubated for $48 \mathrm{~h}$ with linoleic acid $(30 \mu \mathrm{M})$ or 13-HPODE $(30 \mu \mathrm{M})$ at concentrations approximately equivalent to their abundance in $100 \mu \mathrm{g} / \mathrm{ml}$ oxLDL. As shown in Fig. 3, preincubation alone (closed boxes) with unmodified linoleic acid (lane 3), 13-HPODE (lane 5), or oxLDL (lane 7) had no effect on cell surface expression of VCAM-1 $(A)$, ICAM-1 $(B)$, or Eselectin $(C)$, as determined by ELISA in HAECs. Preincubation with linoleic acid had no effect of the ability of TNF $\alpha$ alone (6-h exposure; Fig. 3, lanes 2 and 4$)(100 \mathrm{U} / \mathrm{ml})$ to induce VCAM-1, E-selectin, or ICAM-1 expression. However, preincubation with either 13-HPODE (Fig. 3, lane 6) or oxLDL (lane 8 ) augmented TNF $\alpha$ activation of both VCAM-1 $(A)$ by $71 \%$ and $65 \%$, respectively, and ICAM-1 $(B)$ by $80 \%$ and $43 \%$, respectively, but had no effect on E-selectin expression $(C)$. Under identical experimental conditions, using flow cytometry analysis in HAECs, augmented expression of VCAM-1 by both oxLDL and 13-HPODE occurred uniformly throughout the cell population rather than in a subpopulation of cells (Fig. 4, $A-$ $D)$. This similarity between the effects of oxLDL and 13HPODE on adhesion molecule expression suggests that a fatty acid hydroperoxide, such as 13-HPODE, may play an important 


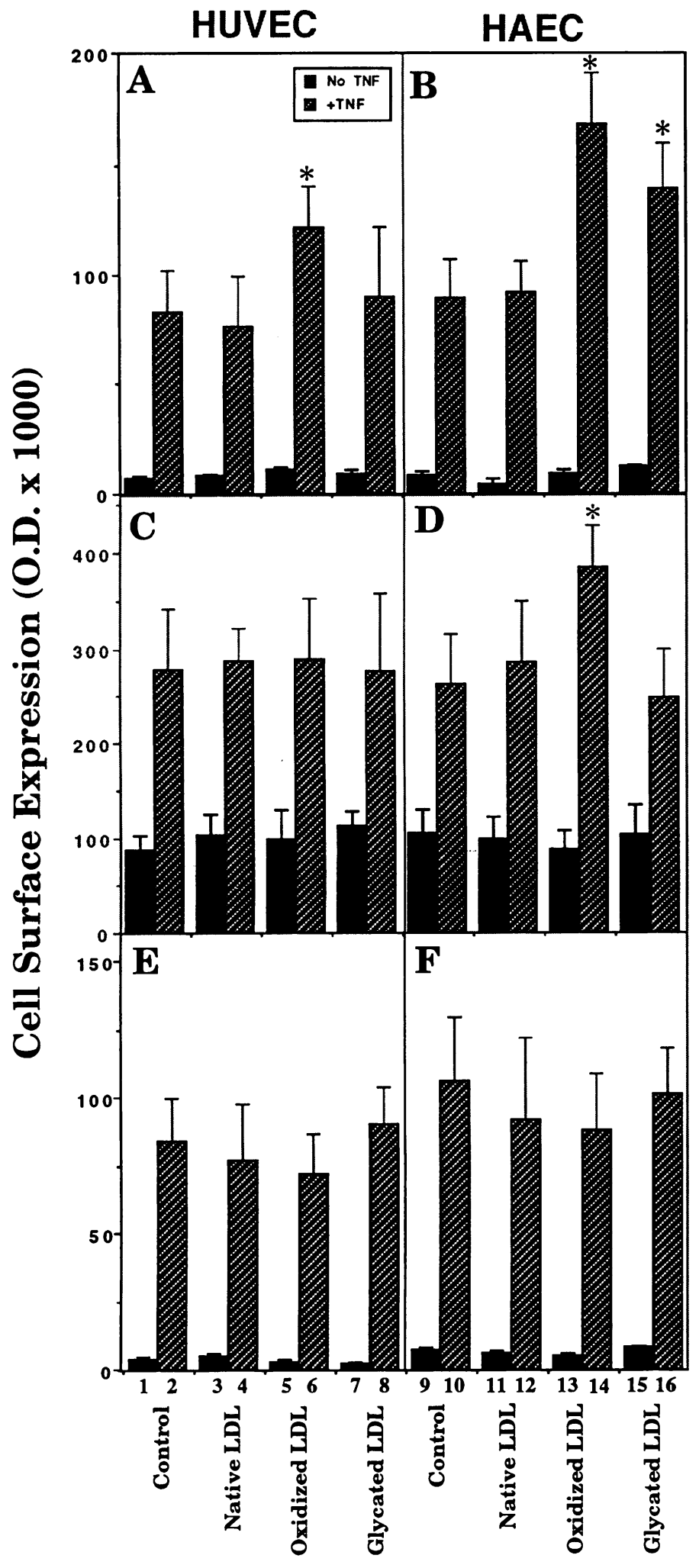

VCAM-1

ICAM-1

Figure 1. Effect of long-term exposure to modified LDL on TNF $\alpha$ regulation of endothelium-mediated cell adhesion molecule expression. HUVECs $(A, C$, and $E$ ) and

E-selectin

HAECs $(B, D$, and $F)$ were plated in 96-well plates, as described in Methods. Cells were incubated for $48 \mathrm{~h}$ with no LDL (Control, lanes $1,2,9$, and 10 ), or with 100 $\mu \mathrm{g} / \mathrm{ml}$ native $\mathrm{LDL}$ (lanes $3,4,11$, and 12 ), oxLDL (lanes $5,6,13$, and 14 ), or glycated LDL (lanes 7, 8, 15, and 16). Cells were then exposed (striped) or not (filled) to $\mathrm{TNF} \alpha(100 \mathrm{U} / \mathrm{ml})$ for a 6-h period. Cell surface expression of $(A)$ VCAM-1, $(B)$ ICAM1 , and $(C)$ E-selectin was determined by ELISA as described in Methods. Values are means \pm SEM and reflect five separate experiments, each performed in triplicate. An asterisk indicates that the value differs $(P<0.05)$ from control.

role in mediating oxLDL regulation of adhesion molecule gene expression in vascular endothelial cells.

As shown in Fig. 5, 13-HPODE enhanced inducible VCAM$1(A)$ and ICAM-1 $(B)$ gene expression over a wide range of TNF $\alpha$ concentrations (10-100 U/ml) but had no effect on Eselectin gene expression $(C)$. This suggests that 13-HPODE not only sensitizes HAECs to TNF $\alpha$ activation of these cell adhesion molecules, but further augments their maximal cytokine-inducible response. To establish whether other significant components of oxLDL modulate cell adhesion molecule expression in an analogous manner, parallel experiments were performed with the phospholipid lyso-PC. Similar to 13- 


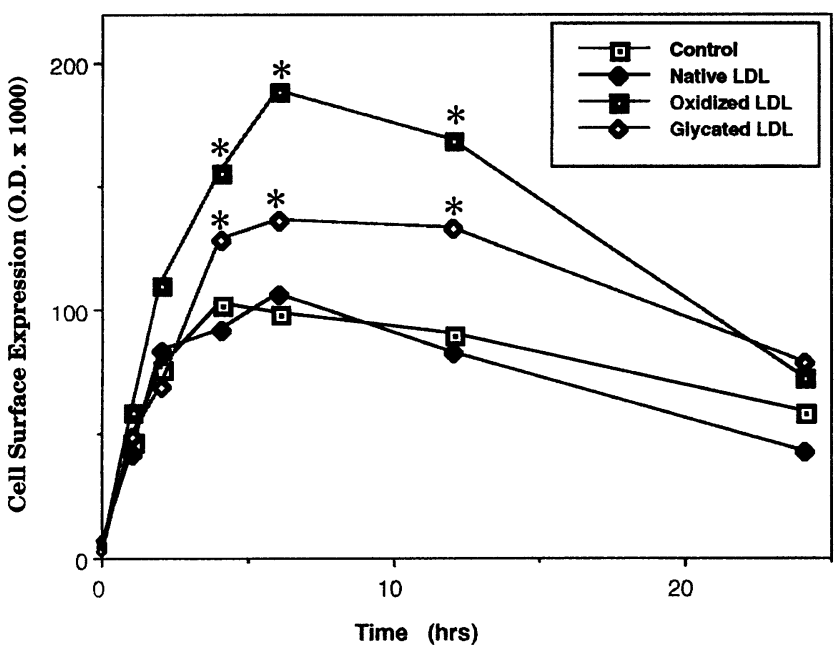

Figure 2. Effect of modified LDL on the kinetics of TNF $\alpha$-mediated activation of VCAM- 1 gene expression. HAECs were plated in 96-well plates and incubated with no LDL (Control), or with $100 \mu \mathrm{g} / \mathrm{ml}$ native LDL, oxLDL, or glycated LDL for $48 \mathrm{~h}$ as described in Methods. HAECs were exposed to TNF $\alpha(100 \mathrm{U} / \mathrm{ml})$. The cells were assayed for cell surface VCAM-1 by ELISA, as described in Methods. Values presented are the means for five separate experiments performed in triplicate. An asterisk indicates that the value differs $(P<0.05)$ from control at its corresponding time point.

HPODE, lyso-PC augmented TNF $\alpha$-activated VCAM- 1 expression at lower TNF $\alpha$ concentrations (up to $25 \mathrm{U} / \mathrm{ml}$ ) (Fig. $5 A$ ) and had no effect on E-selectin expression $(C)$. However, in contrast to 13-HPODE, lyso-PC had no effect on VCAM-1 expression at higher TNF $\alpha$ concentrations; nor did it augment ICAM-1 expression. These results suggest that although 13HPODE and lyso-PC mediate distinct patterns of regulation of cell adhesion molecule expression in HAECs, they share the common feature of augmenting cytokine-activated VCAM-1 gene expression.

13-HPODE augments TNF $\alpha$-induced VCAM-1 gene expression at the mRNA level. To explore whether the augmentation of cytokine-induced VCAM-1 with 13-HPODE is observed at the mRNA level, HAECs were incubated with linoleic acid or 13-HPODE and then exposed to TNF $\alpha(100 \mathrm{U} / \mathrm{ml})$ for $4 \mathrm{~h}$. As shown in Fig. 6, 13-HPODE augmented VCAM-1 (A, lane 6) mRNA accumulation induced by TNF $\alpha$ by $\sim 75 \%$ compared with TNF $\alpha$ alone (lane 4). Under similar conditions, no change was observed in $\beta$-actin (a constitutively expressed gene) mRNA accumulation. No significant VCAM-1 mRNA accumulation was observed in HAECs treated with linoleic acid (Fig. 6 , lane 2) or 13-HPODE (lane 3) for a 48-h period. These results suggest that pretranslational regulatory mechanisms may mediate 13-HPODE augmentation of TNF $\alpha$-induced VCAM- 1 and ICAM-1 gene expression.

13-HPODE augments transcriptional activation of VCAM1 gene expression. To determine whether 13-HPODE affects transcriptional activation of VCAM-1 gene expression induced by cytokine, nuclear run-off analyses were performed. HAECs were incubated with linoleic acid ( $30 \mu \mathrm{M})$ or 13-HPODE (30 $\mu \mathrm{M})$ for $48 \mathrm{~h}$ and then exposed or not to TNF $\alpha(100 \mathrm{U} / \mathrm{ml})$ for $3 \mathrm{~h}$. As demonstrated in Fig. 7, 13-HPODE augmented the activation of transcription of VCAM- 1 induced by TNF $\alpha$ (lane 6 ) by $\sim 55 \%$ compared with TNF $\alpha$ alone (lane 4 ). No changes

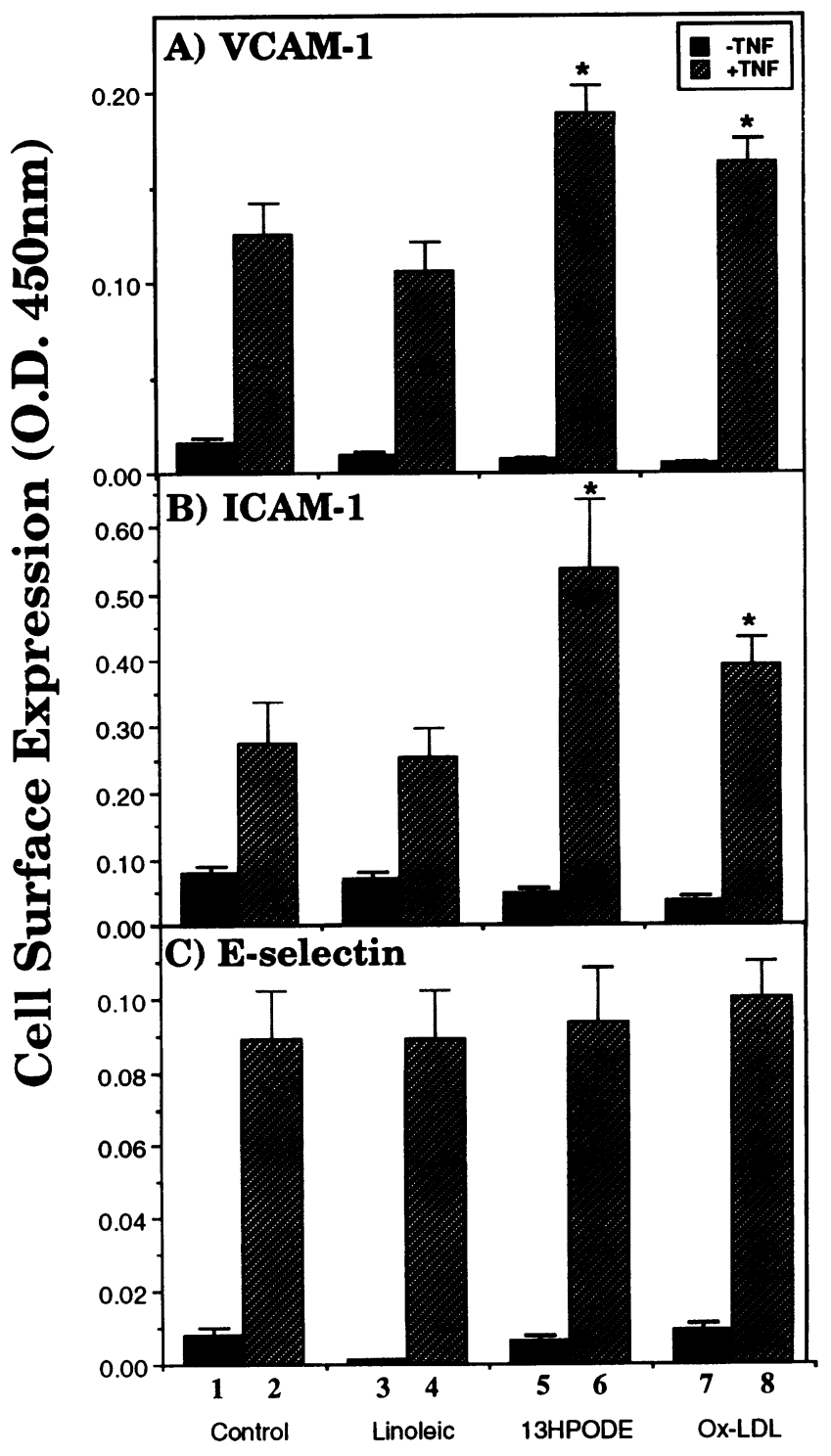

Figure 3. Effect of the lipid hydroperoxide 13-HPODE on TNF $\alpha$ activation of cell adhesion molecule gene expression. HAECs were plated in 96-well plates and incubated with $30 \mu \mathrm{M}$ 13-HPODE, $30 \mu \mathrm{M}$ linoleic acid, or $100 \mu \mathrm{g} / \mathrm{ml}$ oxLDL, incubated (Control) for $48 \mathrm{~h}$. The cells were then exposed (striped) or not (filled) to TNF $\alpha(100 \mathrm{U} / \mathrm{ml})$ for a 6-h period. Cell surface expression of $(A)$ VCAM-1, $(B)$ ICAM-1, and $(C)$ E-selectin was determined by ELISA as described in Methods Values presented are the means \pm SEM for four experiments performed in triplicate. An asterisk indicates that the value differs $(P<0.05)$ from control.

were observed in the transcriptional activity of the $\beta$-actin gene. These findings are in agreement with the results observed with Northern blot analyses measuring mRNA accumulation and suggest that 13-HPODE further enhances the rate of transcription of VCAM-1 induced by TNF $\alpha$.

\section{Discussion}

In the inflammatory response characteristic of early atherogenesis, the interaction of mononuclear leukocytes with vascular endothelial cells is likely mediated by a complex amalgam of 


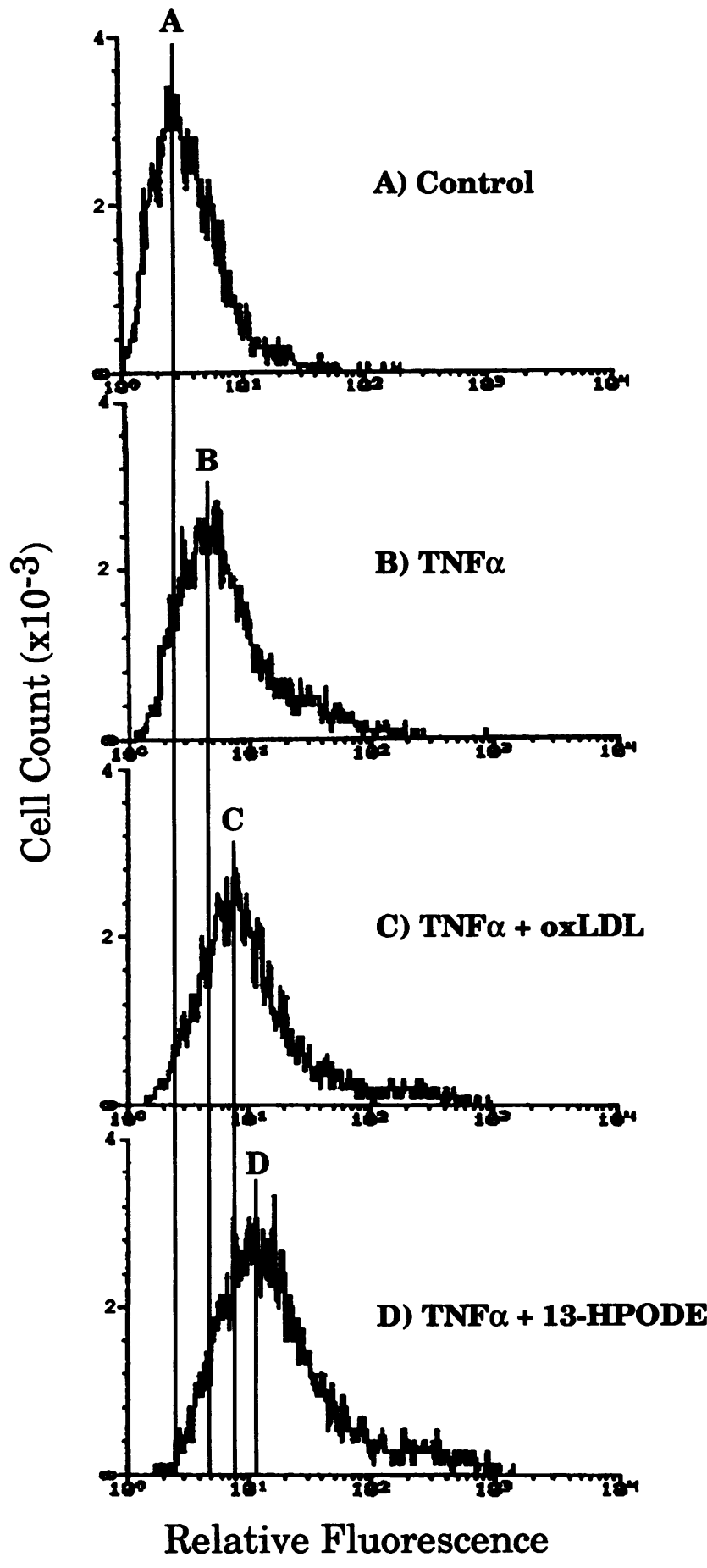

Figure 4. 13-HPODE and oxLDL augment TNF $\alpha$-induced VCAM-1 expression in a uniform HAEC population. Confluent HAECs were pretreated with either oxLDL $(100 \mu \mathrm{g} / \mathrm{ml})$ or 13-HPODE $(30 \mu \mathrm{M})$ in M199 medium for $48 \mathrm{~h}$ and then exposed to TNF $\alpha(100 \mathrm{U} / \mathrm{ml})$ for $6 \mathrm{~h}$. Cell surface expression of VCAM-1 in $(A)$ control, $(B)$ TNF $\alpha$, (C) TNF $\alpha+$ oxLDL, and (D) TNF $\alpha+13$-HPODE was measured by fluorescence immunobinding assay using flow cytometry, as described in Methods. Specific cell surface mAb binding in this assay was calculated by subtracting the fluorescence detected in endothelial cell monolayers incubated in the absence of primary mAb. The $\mathrm{x}$-axis represents the relative fluorescence; the $y$-axis represents the total number of cells at each fluorescence signal. The figures shown are a representative experiment performed on three separate occasions.

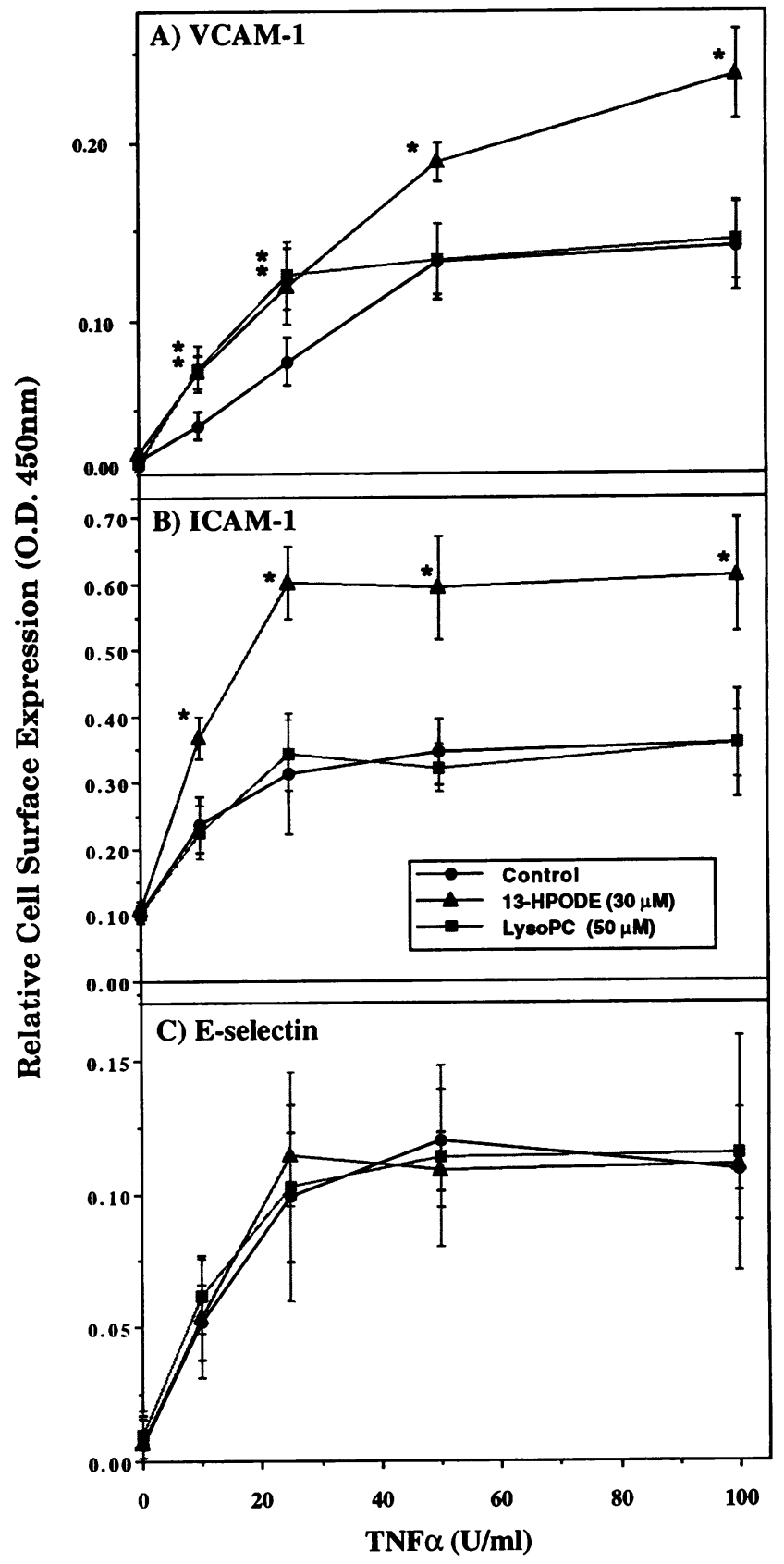

Figure 5. Effect of 13-HPODE and lyso-PC on the TNF $\alpha$ dose response of cell adhesion molecule gene expression. HAECs were plated in 96well plates and incubated with no compound (Control), or with $30 \mu \mathrm{M}$ 13-HPODE or $50 \mu \mathrm{M}$ lyso-PC for $48 \mathrm{~h}$, as described in Methods. HAECs were exposed to differing concentrations of TNF $\alpha(10,25,50$, and 100 $\mathrm{U} / \mathrm{ml}$ ) for a period of $6 \mathrm{~h}$. Cell surface expression of $(A)$ VCAM-1, $(B)$ ICAM-1, and $(C)$ E-selectin was determined by ELISA as described in Methods. Values presented are the means for three experiments performed in triplicate. An asterisk indicates that the value differs ( $P$ $<0.05$ ) from control at its corresponding dose of TNF $\alpha$.

interacting regulatory signals. A common feature underlying these complex regulatory interactions may involve redox-sensitive nuclear regulatory factors that modulate the expression of gene products such as the endothelial adhesion molecule VCAM-1 (13). Using this molecular model, we have explored whether oxLDL, a potentially important regulator of atherogen- 


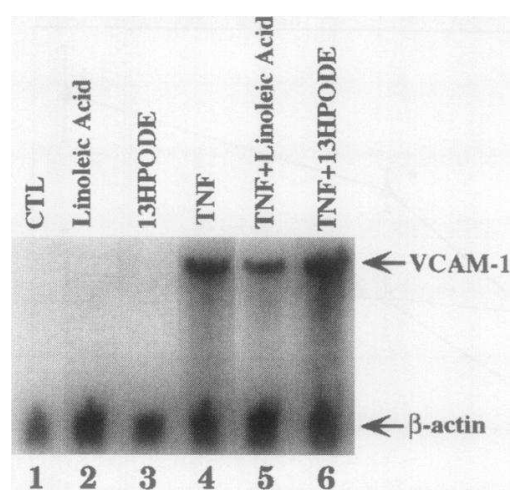

Figure 6. 13-HPODE augments TNF $\alpha$-induced mRNA accumulation of VCAM- 1 and ICAM- 1 in HAECs. After pretreatment with linoleic acid $(30 \mu \mathrm{M})$ or 13 -HPODE $(30 \mu \mathrm{M})$ for $48 \mathrm{~h}$, HAECs were exposed to $\mathrm{TNF} \alpha(100 \mathrm{U} / \mathrm{ml})$ for a 3-h period. Total RNA was isolated and $20 \mu \mathrm{g}$ size fractionated by denaturing $1.0 \%$ agaroseformaldehyde gel elec-

trophoresis, transferred to nitrocellulose, hybridized to either ${ }^{32} \mathrm{P}$-labeled human VCAM-1 -specific $(A)$ or $\beta$-actin-specific $(B) \mathrm{cDNA}$, and visualized by autoradiography. After washes, filters were exposed to $\mathrm{x}$-ray film at $-70^{\circ} \mathrm{C}$ with one intensifying screen for $24 \mathrm{~h}$. Lanes are identified as follows: lane 1, control; lane 2, linoleic acid; lane 3, 13-HPODE; lane 4, TNF $\alpha$; lane 5, TNF $\alpha+$ linoleic acid; lane 6, TNF $\alpha+13$ HPODE.

esis, might function at least in part through modulation of redoxsensitive VCAM-1 gene expression. In this study, we have established that long-term exposure to either oxLDL or the fatty acid hydroperoxide (13-HPODE) and phospholipid (lyso-PC) components of oxLDL augments the ability of vascular endothelial cells from different vascular beds to express VCAM-1 in response to a cytokine inflammatory signal. These findings support the notion that naturally occurring oxidant signals may sensitize the vasculature to inflammatory signals through modulation of endothelial adhesion molecule gene expression.

Oxidative modification of LDL is an important early event in atherogenesis (18). Most studies have focused on the role of oxLDL alone as a primary regulator of cellular function and gene expression $(17,18)$, whereas little is known of the role of oxLDL in modulating the response of endothelial cells to other important factors resident in the atherosclerotic plaque, such as cytokines (42). We have established that long-term exposure to oxLDL ( $48 \mathrm{~h}$ ) augments the ability of cultured endothelial cells from two distinct vascular beds, HAECs (arterial) and HUVECs (venous), to activate VCAM-1 gene expression in response to the cytokine TNF $\alpha$. A similar effect was observed for ICAM-1 in HAECs, but not HUVECs. Toxic responses were not visually observed in these studies, and the ability of both cell types to induce E-selectin gene expression under the identical experimental conditions was unaffected. In the absence of cytokine, these same cells are indistinguishable from control cells relative to adhesion molecule expression. Indeed, basal expression of ICAM-1 characteristic of both cell types was not markedly affected by oxLDL. These observations argue that the effect of oxLDL on TNF $\alpha$-mediated VCAM-1 adhesion molecule expression was specific, mediated neither by a toxic response nor a general enhancement of TNF $\alpha$-mediated signals. Although the oxidative modification of LDL likely confers the regulatory effect, possibly through a subsequent intracellular redox-sensitive signal, we have not directly determined whether oxLDL has a direct or indirect effect on the intracellular redox state. It is possible that differences in uptake mechanisms between modified and unmodified LDL could mediate a differential regulatory effect. Indeed, uptake through the scavenger

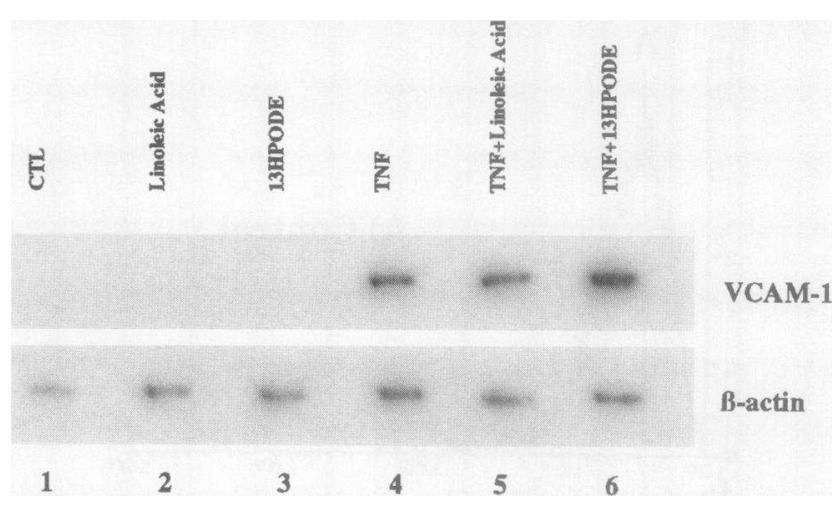

Figure 7. 13-HPODE augments TNF $\alpha$-induced transcriptional activation of VCAM-1 gene expression. After pretreatment with linoleic acid (30 $\mu \mathrm{M})$ or 13-HPODE ( $30 \mu \mathrm{M})$ for $48 \mathrm{~h}$, HAECs were exposed to TNF $\alpha$ $(100 \mathrm{U} / \mathrm{ml}$ ) for a 3-h period. Nuclei were isolated and labeled with $[\alpha-$ ${ }^{32} \mathrm{P}$ ]UTP. The RNA was isolated and then hybridized to filter-immobilized, denatured plasmids containing specific cDNA inserts ( $10 \mu \mathrm{g}$ of DNA per slot) of VCAM-1 and $\beta$-actin. After washes, filters were imaged using the PhosphorImager 445Si and the NIH Image $1.55 \mathrm{com}$ puter software. Lanes are identified as follows: lane 1 , control; lane 2 , linoleic acid; lane 3, 13-HPODE; lane 4, TNF $\alpha$; lane 5, TNF $\alpha$ + linoleic acid; lane 6 , TNF $\alpha+13$-HPODE.

receptor might mediate increased oxLDL uptake relative to unmodified LDL uptake via the LDL receptor (20).

We also established that long-term exposure to another form of modified LDL, glycated LDL, appears to function in a manner analogous to oxLDL by augmenting cytokine activation of endothelial cell VCAM-1 gene expression. Glycated LDL is a modified form of LDL found in the serum of patients with diabetes mellitus (24). Uptake and metabolism of the glycated LDL particle by endothelial cells may be distinct from that of oxLDL and may, through distinct, intracellular mechanisms, modulate expression of cell surface VCAM-1. Nevertheless, this observation suggests a possible functional link between vascular inflammatory processes, atherosclerosis, and diabetes mellitus. It may be that nonenzymatic glycation of proteins, by its association with cytokines and/or endothelial cells, either directly or indirectly induces the expression of genes encoding these cell adhesion molecules (25).

The blood vessel origin of the endothelial cell appears to play a role in the response to the modulatory effect of oxLDL on adhesion molecule expression. Although oxLDL enhanced cytokine activation of VCAM-1 expression in both HUVECs and HAECs, ICAM-1 expression was similarly enhanced only in HAECs. In addition, and although only semiquantitative, there was a somewhat larger increase in VCAM-1 cell surface expression induced by TNF $\alpha$ in HAECs compared with HUVECs when exposed to oxidized and glycated LDL. These differences are not surprising, as considerable differences in functional and regulatory properties characterize endothelial cells derived from different vascular beds in culture, as well as intact vessels in vivo (31). In our studies, this suggests that arterialderived endothelial cells such as HAECs may be more sensitive to extracellular oxidative signals than venous-derived HUVECs. Possible differences in the intrinsic redox properties of cell growth and medium conditions could also play a role and are currently being investigated. Additional factors, such as tissuespecific transcriptional regulatory factors, may also be important 
in regulating the extent of cell adhesion molecule gene expression.

A major outstanding issue concerning the role of oxLDL in atherogenesis focuses on the nature of the active chemical moiety(ies) that mediate its functional and regulatory properties. oxLDL is a complex molecule that contains several distinct biochemical moieties, each of which has been implicated in the atherosclerotic process (18-20). The chemical structure of oxLDL generated within the vessel wall in vivo may not be precisely replicated by the wide variety of in vitro modification techniques used (43-45), thus complicating a comparison of in vitro study results. Although their relative abundance may vary greatly, fatty acid hydroperoxides (notably 13-HPODE) and lyso-PC are consistently observed components of oxLDL (23). We have established that oxLDL and its constituents 13HPODE and lyso-PC share the common property of augmenting TNF $\alpha$-activated VCAM-1 gene expression. However, two distinct patterns of regulation are apparent. First, both oxLDL and 13-HPODE enhance VCAM-1 expression at low $(<25 \mathrm{U} / \mathrm{ml})$ and high $(>50 \mathrm{U} / \mathrm{ml})$ levels of TNF $\alpha$ stimulation, whereas lyso-PC enhances expression only at low levels of TNF $\alpha$. Thus, lyso-PC sensitizes endothelial cells to TNF $\alpha$ regulatory signals without altering the maximal TNF $\alpha$ response, whereas oxLDL and 13-HPODE sensitize and augment maximal response. Second, lyso-PC selectively augments VCAM-1 but not ICAM-1 expression, whereas oxLDL and 13-HPODE augment the expression of both genes in HAECs. These results suggest that lyso-PC may play an important role in initiating VCAM-1mediated immune interactions in response to weak inflammatory signals characteristic of the early atherogenic lesion. oxLDL and 13-HPODE may not only contribute to this effect, but may also augment VCAM-1 - as well as ICAM-1-mediated immune responses owing to the stronger inflammatory signals found later in the maturing atherogenic lesion. Although the underlying molecular mechanisms are not yet known, differences in the regulation of distinct signal transduction pathways for lyso-PC $(31,46)$ and 13-HPODE $(45,47)$ and their interactions with $\mathrm{TNF} \alpha$-mediated signals $(1,2)$ likely underlie this regulatory effect.

Cellular lipoxygenases, such as 15-lipoxygenase, play a role not only in the generation of oxLDL, but also in the generation of intracellular fatty acid hydroperoxides $(23,45,47)$. In the context of VCAM-1 expression, fatty acid peroxides may also potentially serve as part of an intracellular, oxidation-sensitive signal transduction system controlling VCAM-1 expression. Through conversion of the major cellular reducing agent, glutathione, to oxidized glutathione, fatty acid hydroperoxides are normally detoxified by the enzyme, glutathione peroxidase (48). Dithiocarbamates, such as diethyldithiocarbamate and pyrrolidine dithiocarbamate, act as inducers of glutathione peroxidase activity and prevent not only the decrease in glutathione peroxidase activity, but also the decrease in reduced/oxidized glutathione ratio observed in cells challenged with phorbol esters (49). Through conversion of fatty acid hydroperoxides to non-hydroperoxide-containing compounds, these antioxidants may modulate VCAM-1 gene expression. Although not directly tested, our studies would suggest that the generation of a fatty acid hydroperoxide, such as 13-HPODE, may serve as a second messenger signal in cytokine-mediated VCAM-1 gene expression. A direct role for 13-HPODE on VCAM-1 transactivation and NF- $\kappa \mathrm{B}$ activation is now under study.

Our findings suggest that the degree to which 13-HPODE and lyso-PC are generated within the LDL molecule may underlie some of the heterogeneity observed in some of the biological effects of LDL modified by different in vitro oxidation techniques $(3,31)$. For example, recent investigations have shown that minimally modified LDL activates cultured endothelial cells to increase their interaction with monocytes but not neutrophils $(42,49)$. In the same study, copper-oxidized LDL demonstrated relatively minimal activity. Additionally, minimally modified LDL stimulates production of monocyte chemotactic protein-1 in cells (49), whereas the effect of metal-oxidized LDL is less pronounced (50). It is interesting that minimally modified LDL is produced in vitro using soybean lipoxygenase and phospholipase $A_{2}$. It is possible that the 13-HPODE (synthesized via lipoxygenase as well) that we used in our experiments might function as a biologically active component of minimally modified LDL when presented to the endothelial cell in vivo.

In summary, our findings demonstrate that the ability of endothelial cells to express specific cell surface adhesion molecules in response to a cytokine signal may be modulated by a naturally occurring oxidant signal, oxLDL, and its significant components, 13-HPODE and lyso-PC. The molecular mechanisms underlying the preferential response of VCAM-1, regardless of endothelial cell type, may be a function of its distinctive, redox-sensitive mode of regulation (13). The mechanisms regulating ICAM-1 expression are less clear but may involve tissuespecific factors, whereas E-selectin gene expression does not appear to be modulated by these natural oxidants. As the type of inflammatory response in vascular diseases such as atherosclerosis is defined at least in part by the types of cell adhesion molecules expressed by activated endothelial cells, differential regulation of these genes by oxidant signals may underlie the characteristic pattern of inflammation observed in this disease state.

\section{Acknowledgments}

We wish to thank Dr. Margaret K. Offermann and Ms Renee Shaw for their assistance on the flow cytometry experiments and Ms Xiao Peng Meng for her assistance on the nuclear run-off experiments.

This work was supported in part by grant PO1 HL48667 from the National Institutes of Health (to R. W. Alexander and R. M. Medford). R. M. Medford is an Established Investigator of the American Heart Association.

\section{References}

1. Libby, P., and G. K. Hanson. 1991. Biology of disease. Involvement of the immune system in human atherogenesis: current knowledge and unanswered questions. Lab. Invest. 64:5-13.

2. Hajjar, D. P., and K. B. Pomerantz. 1992. Signal transduction in atherosclerosis: integration of cytokines and the eicosanoid network. FASEB (Fed. Am. Soc. Exp. Biol.) J. 6:2933-2941.

3. Clinton, S. K., R. Underwood, L. Hayes, M. L. Sherman, D. W. Kufe, and P. Libby. 1992. Macrophage colony-stimulating factor mRNA and protein in atherosclerotic lesion of rabbits and humans. Am. J. Pathol. 140:301-316.

4. Yla-Herttuala, S., B. A. Lipton, M. E. Rosenfeld, T. Sarkioja, T. Yoshimura, E. J. Leonard, J. L. Witztum, and D. Steinberg. 1991. Expression of MCP-1 in macrophage-rich areas of human and rabbit atherosclerotic lesions. Proc. Natl. Acad. Sci. USA. 88:5252-5256.

5. Liao, F., A. Andalibi, F. C. deBeer, A. M. Fogelman, and A. J. Lusis. 1993. Genetic control of inflammatory gene induction and NF- $\kappa$ B-like transcription factor activation in response to an atherogenic diet in mice. J. Clin. Invest. 91:2572-2579.

6. Bevilacqua, M. P., J. S. Pober, M. E. Wheeler, R. S. Cotran, and M. A. Gimbrone. 1985. Interleukin-1 acts on cultured human vascular endothelium to 
increase the adhesion of polymorphonuclear leukocytes, monocytes, and related leukocyte cell lines. J. Clin. Invest. 76:2003-2011.

7. Carlos, T. M., B. R. Schwartz, N. L. Kovach, E. Yee, M. Rosa, L. Osborn, G. Chi-Rosso, B. Newman, and R. Lobb. 1990. Vascular cell adhesion molecule-1 mediates lymphocyte adherence to cytokine-activated cultured human endothelial cells. Blood. 76:965-970.

8. Rollins, B. J., T. Yoshimura, E. J. Leonard, and J. S. Pober. 1990. Cytokineactivated human endothelial cells synthesize and secrete a monocyte chemoattractant, MCP-1/JE. Am. J. Pathol. 136:1229-1233.

9. Parhami, F., Z. T. Fang, A. M. Fogelman, A. Andalibi, M. C. Territo, and J. A. Berliner. 1993. Minimally modified low density lipoprotein-induced inflammatory responses in endothelial cells are mediated by cyclic adenosine monophosphate. J. Clin. Invest. 92:471-478.

10. Hahne, M., U. Jager, S. Isenmann, R. Hallmann, and D. Vestweber. 1993. Five tumor necrosis factor-inducible cell adhesion mechanisms on the surface of mouse endothelioma cells mediate the binding of leukocytes. J. Cell Biol. 121:655-664

11. Osborn, L. 1990. Leukocyte adhesion to endothelium in inflammation. Cell. 62:3-6.

12. Butcher, E. D. 1991. Leukocyte-endothelial cell recognition: three or more steps to specificity and diversity. Cell. 67:1033-1036.

13. Marui, N., M. K. Offermann, R. Swerlick, C. Kunsch, C. A. Rosen, M. Ahmad, R. W. Alexander, and R. M. Medford. 1993. VCAM-1 gene transcription and expression are regulated through an antioxidant-sensitive mechanism in human vascular endothelial cells. J. Clin. Invest. 92:1866-1874.

14. Pober, J. S., and R. S. Cotran. 1991. What can be learned from the expression of endothelial adhesion molecules in tissues? Lab. Invest. 64:301305.

15. Shimizu, Y., W. Newman, Y. Tanaka, and S. Shaw. 1992. Lymphocyte interactions with endothelial cells. Immunol. Today. 13:106-112.

16. O’Brien, K. D., M. D. Allen, T. O. McDonald, A. Chait, J. M. Harlan, D. Fishbein, J. McCarty, M. Ferguson, K. Hudkins, C. D. Benjamin, R. Lobb, and C. E. Alpers. 1993. Vascular cell adhesion molecule-1 is expressed in human coronary atherosclerotic plaques. J. Clin. Invest. 92:945-951

17. Yla-Herttuala, S., S. W. Pawlinski, M. E. Rosenfeld, S. Parthasarathy, T. E. Carew, S. Butler, J. L. Witztum, and D. Steinberg. 1989. Evidence for the presence of oxidatively modified low density lipoprotein in atherosclerotic lesions of rabbit and man. J. Clin. Invest. 84:1086-1095.

18. Witztum, J. L., and D. Steinberg. 1991. Role of oxidized low density lipoprotein in atherogenesis. J. Clin. Invest. 88:1785-1792.

19. Yla-Herttuala, S. 1991. Macrophages and oxidized low density lipoproteins in the pathogenesis of atherosclerosis. Ann. Med. 23:561-567.

20. Henriksen, T., E. M. Mahoney, and D. Steinberg. 1981. Enhanced macrophage degradation of low density lipoprotein previously incubated with cultured endothelial cells: recognition by receptor for acetylated low density lipoprotein. Proc. Natl. Acad. Sci. USA. 78:6499-6503.

21. Sparrow, C. P., S. Parthasarathy, and D. Steinberg. 1988. Enzymatic modification of low density lipoprotein by purified lipoxygenase plus phospholipase $\mathrm{A}_{2}$ mimics cell-mediated oxidative modification. J. Lipid Res. 29:745-753.

22. Henriksson, P., M. Hamberg, and U. Diczfalusy. 1985. Formation of 15HETE as a major hydroxyeicosatetraenoic acid in the atherosclerotic vessel wall. Biochim. Biophys. Acta. 834:272-274.

23. Yla-Herttuala, S., M. E. Rosenfeld, S. Parthasarathy, E. Sigal, T. Sarkioja, J. L. Witztum, and D. Steinberg. 1991. Gene expression in macrophage-rich human atherosclerotic lesions: 15-lipoxygenase and acetyl LDL receptor mRNA colocalize with oxidation-specific lipid-protein adducts. J. Clin. Invest. 87:11461152 .

24. Lyons, T. J. 1993. Glycation and oxidation: a role in the pathogenesis of atherosclerosis. Am. J. Cardiol. 71:26B-31B

25. Richardson, M., S. J. Hadcock, M. DeReske, and M. I. Cybulsky. 1994. Increased expression in vivo of VCAM-1 and E-selectin by the aortic endothelium of normolipemic and hyperlipemic diabetic rabbits. Arterioscler. Thromb. 14:760769 .

26. Krolewski, A. S., J. H. Warram, P. Valsania, B. C. Martin, L. M. B. Laffel, and A. R. Christlieb. 1991. Evolving natural history of coronary artery disease in diabetes mellitus. Am. J. Med. 90:56S-61S.

27. Factor, S. M., B. H. Segal, and K. H. van Hoeven. 1992. Diabetes and coronary artery disease. Coron. Art. Dis. 3:4-10.

28. Navab, M., S. S. Imes, S. Y. Hama, G. P. Hough, L. A. Ross, R. W. Bork, A. J. Valente, J. A. Berliner, D. C. Drinkwater, H. Laks, and A. M. Fogelman. 1991. Monocyte transmigration induced by modification of low density lipoprotein in coculture of human aortic wall cells is due to induction of MCP-1 and is abolished by high density lipoprotein. J. Clin. Invest. 88:2039-2046.

29. Kugiyama, K., S. A. Kerns, J. D. Morrisett, R. Roberts, and P. D. Henry. 1990. Impairment of endothelium-dependent arterial relaxation by lysolecithin in modified low-density lipoproteins. Nature (Lond.). 344:160-162.

30. Simon, B. C., L. D. Cunningham, and R. A. Cohen. 1990. Oxidized lowdensity lipoproteins cause contraction and inhibit endothelium-dependent relaxation in the pig coronary artery. J. Clin. Invest. 86:75-79.

31. Kume, N., M. I. Cybulsky, and M. A. Gimbrone. 1992. Lysophosphatidylcholine, a component of atherogenic lipoproteins, induces mononuclear leukocyte adhesion molecules in cultured human and rabbit arterial endothelial cells. $J$. Clin. Invest. 90:1138-1144.

32. Hamilton, T. A., G. Ma, and G. M. Chisholm. 1990. Oxidized low density lipoprotein suppresses the expression of TNF $\alpha$ mRNA in stimulated murine peritoneal macrophages. J. Immunol. 144:2343-2350.

33. Schleicher, E., T. Deufel, and O. H. Wieland. 1981. Non-enzymatic glycosylation of human serum lipoproteins. FEBS (Fed. Eur. Biochem. Soc.) Lett. 129:1-4.

34. Schuh, J., G. F. Fairclough, and R. H. Haschemeyer. 1978. Oxygenmediated heterogeneity of apo-low density lipoprotein. Proc. Natl. Acad. Sci. USA. 75:3173-3178.

35. Lowry, O. H., N. J. Rosebrough, A. L. Farr, and R. J. Randall. 1951. Protein measurement with the Folin phenol reagent. J. Biol. Chem. 193:265-268.

36. Gonen, B., J. Baenziger, G. Schonfeld, D. Jacobsen, and M. P. Farrar. 1978. Non-enzymatic glycosylation of low-density lipoproteins in vitro. Diabetes. 30:875-878.

37. Jougasaki, M., K. Kugiyama, Y. Saito, K. Nakao, H. Imura, and H. Yasue. 1992. Suppression of endothelin-1 secretion by lysophosphatidylcholine in cultured vascular endothelial cells. Circ. Res. 71:614-619.

38. Yla-Herttuala, S., M. E. Rosenfeld, S. Parthasarathy, C. K. Glass, E. Sigal, J. L. Witztum, and D. Steinberg. 1990. Colocalization of 15-lipoxygenase mRNA and protein with epitopes of oxidized low density lipoprotein in macrophage-rich areas of atherosclerotic lesions. Proc. Natl. Acad. Sci. USA. 87:6959-6963.

39. Jeng, J.-R., C.-H. Chang, S.-M. Shieh, and H.-C. Chiu. 1993. Oxidized low-density lipoprotein enhances monocyte-endothelial cell binding against shearstress-induced detachment. Biochim. Biophys. Acta. 1178:221-227.

40. Chomczynski, P., and N. Sacchi. 1987. Single-step method of RNA isolation by acid guanidinium thiocyanate-phenol-chloroform extraction. Anal. Biochem. 162:156-159.

41. Greenberg, M. E., and T. P. Bender. 1993. Identification of newly transcribed RNA. In Current Protocols in Molecular Biology. F. Ausubel, R. Brent, R. E. Kingston, D. D. Moore, J. G. Seidman, J. A. Smith, and K. Struhl, editors. John Wiley \& Sons, Inc., New York.

42. Barath, P. D., M. C. Fishbein, J. Cao, J. Berenson, R. H. Helfant, and J. S. Forrester. 1990. Detection and localization of tumor necrosis factor in human atheroma. Am. J. Cardiol. 65:297-302.

43. Berliner, J. A., M. C. Territo, A. Sevanian, S. Ramin, J. A. Kim, B. Bamshad, M. Esterson, and A. M. Fogelman. 1990. Minimally modified LDL stimulates monocyte endothelial interactions. J. Clin. Invest. 85:1260-1266.

44. Kume, N., H. Arai, C. Kawai, and T. Kita. 1991. Receptors for modified low-density lipoproteins in human endothelial cells: different recognition for acetylated low-density lipoprotein and oxidized low-density lipoprotein. Biochim. Biophys. Acta. 1091:63-67.

45. Chisholm, G. M. 1991. Antioxidants and atherosclerosis: a current assessment. Clin. Cardiol. 14:I-25-30.

46. Kume, N., and M. A. Gimbrone. 1994. Lysophosphatidylcholine transcriptionally induces growth factor gene expression in cultured human endothelial cells. J. Clin. Invest. 93:907-911.

47. Rankin, S., S. Parthasarathy, and D. Steinberg. 1991. Evidence for a dominant role of lipoxygenase (s) in the oxidation of LDL by mouse peritoneal macrophages. J. Lipid Res. 32:155-161.

48. Perchellet, E. M., E. A. Maatta, N. L. Abney, and J.-P. Perchellet. 1987. Effects of diverse intracellular thiol delivery agents on glutathione peroxidase activity, the ratio of reduced/oxidized glutathione, and ornithine decarboxylase induction in isolated mouse epidermal cells treated with 12-O-tetradecanoylphorbol-13-acetate. J. Cell. Physiol. 131:64-73.

49. Cushing, S. D., J. A. Berliner, A. J. Valentine, M. C. Territo, M. Navab, F. Parhami, R. Gerrity, C. J. Schwartz, and A. M. Fogelman. 1990. Minimally modified LDL induces MCP-1 in human endothelial cells and smooth muscle cells. Proc. Natl. Acad. Sci. USA. 87:5134-5138.

50. Parhami, F., Z. T. Fang, A. M. Fogelman, A. Andalibi, M. C. Territo, and J. A. Berliner. 1993. Minimally modified low density lipoprotein-induced inflammatory responses in endothelial cells are mediated by cAMP. J. Clin. Invest. $92: 471-478$. 